\section{Survey of Cultural Practices Used in Production of Wintercreeper Euonymus}

\author{
Cheryl R. Boyer ${ }^{1,3}$, Janet C. Cole ${ }^{1,4,5}$, and Mark E. Payton ${ }^{2,4}$
}

ADDITIONAL INDEX WORDS. anthracnose, Colletotrichum gloeosporioides, Euonymus fortunei, disease

SUMMARY. A survey of commercial nursery growers was conducted to identify cultural practices used in wintercreeper euonymus (Euonymus fortune $i$ ) production. Growers that have or have not experienced anthracnose incited by Colletotrichum gloeosporioides on wintercreeper euonymus participated in the survey. Nurseries reported using a variety of practices to produce quality plants for sale. Plant culture appeared similar between nurseries with anthracnose problems on wintercreeper euonymus and those without anthracnose problems.

W intercreeper euonymus is a fast-growing, woody evergreen species that is used to add color to the landscape. Numerous cultivars with different growth habits and leaf variegation patterns have been described (Dirr, 1998; Whitcomb, 1996). Wintercreeper euonymus is an integral part of the nursery inventory because of the cultivars available and popularity with consumers.

Wintercreeper euonymus is susceptible to Colletotrichum gloeosporioides during production and in the landscape, resulting in anthracnose symptoms. Mahoney and Tattar (1980a, b) first identified anthracnose incited by $C$. gloeosporioides on fieldand container-grown wintercreeper euonymus from several New England nurseries in 1978. Typical disease symptoms included leaf and stem lesions, stem dieback, and defoliation.

Mahoney and Tattar (1980a, b) noted that maneb, mancozeb, and chlorothalonil controlled anthracnose symptoms on wintercreeper euonymus. Recent studies have shown that mancozeb reduces but does not eliminate anthracnose symptoms (Boyer et al., 2007; Cole et al.,

This project was supported under project OKL02324.

The assistance of Rhiannon Battles, Senior Secretary, and Autumn Nolting, Student Worker, Department of Horticulture and Landscape Architecture, Oklahoma State University in creating and maintaining the database and mailing surveys is greatly appreciated.

${ }^{1}$ Department of Horticulture and Landscape Architecture, Oklahoma State University, $360 \mathrm{Ag}$ Hall, Stillwater, OK 74078-6027

${ }^{2}$ Statistics Department, Oklahoma State University, 301 MSCS Building, Stillwater, OK 74078

${ }^{3}$ Former graduate research assistant.

${ }^{4}$ Professor.

${ }^{5}$ Corresponding author. E-mail: janet.cole@okstate.edu.
2005; Ningen, 2003; SchupbachNingen et al., 2006). This indicates that C. gloeosporioides has developed resistance to mancozeb. Other fungicides, including thiophanate-methyl (LaMondia, 200la, b; Ningen, 2003), copper hydroxide (Cole et al., 2005; LaMondia, 200la, b), azoxystrobin (Cole et al., 2005; LaMondia 2001a), myclobutanil (Cole et al., 2005), trifloxystrobin (Cole et al., 2005; Schupbach-Ningen et al., 2006), propiconazole (Ningen, 2003), iprodione (LaMondia, 2001b), and copper sulfate pentahydrate (Boyer et al., 2007), have also been tested with little success in controlling anthracnose symptoms on wintercreeper euonymus.

An alternative to using fungicides to control anthracnose symptoms is an altered growing environment that reduces plant stress and creates less favorable conditions for C. gloeosporioides growth. Ningen et al. (2004) found that disease symptoms were more severe on plants grown with $28.6^{\circ} \mathrm{C}$ than $19.3^{\circ} \mathrm{C}$ night temperatures. Subsequent research showed that anthracnose symptoms decreased as shade intensity under which plants were grown increased (Ningen et al., 2005 ). Disease severity was also lower when plants were irrigated in the afternoon rather than in the early morning (Ningen et al., 2005).

The objective of this research was to identify cultural practices used in commercial production of wintercreeper euonymus by nurseries that do and those that do not experience anthracnose on wintercreeper euonymus.

\section{Materials and methods}

A list of production nurseries was obtained from the American Nursery and Landscape Association. Based on nursery name and information obtained from websites, nurseries that did not grow wintercreeper euonymus were eliminated, leaving a mailing list of 448 nurseries. On 2 Mar. 2005 each nursery was mailed a letter describing the project, a survey, and a postage-paid envelope in which to return the completed survey. The nurseries were also given the option of completing the survey online. About 6 weeks after the first mailing, follow-up letters and surveys were mailed to nurseries that had not responded. This was repeated again $\approx 6$ weeks after the second mailing if no response was received.

All data were analyzed using SAS (PC SAS version 9; SAS Institute, Cary, NC). Each response was entered as an observation in the data set. Relationships among the responses to various questions were assessed by constructing two-way contingency tables using PROC FREQ in SAS.

\section{Results and discussion}

Of 448 surveys mailed, 242 (54\%) were completed and returned. Three respondents used the online survey and the other 239 returned paper surveys in the postage-paid envelopes provided. Twenty-two respondents indicated that they grew wintercreeper euonymus at one time but no longer produce it whereas 62 respondents said that they currently grow wintercreeper euonymus. Only surveys from nurseries that currently grow wintercreeper euonymus or have grown it in the past were included in data analysis. Most of the respondents that currently grow wintercreeper euonymus were located in the midwestern United States

\begin{tabular}{llll}
\hline $\begin{array}{l}\text { Units } \\
\text { To convert U.S. to SI, } \\
\text { multiply by }\end{array}$ & U.S. unit & SI unit & $\begin{array}{l}\text { To convert SI to U.S., } \\
\text { multiply by }\end{array}$ \\
\hline 3.7854 & gal & L & 0.2642 \\
$\left({ }^{\circ} \mathrm{F}-32\right) \div 1.8$ & ${ }^{\circ} \mathrm{F}$ & ${ }^{\circ} \mathrm{C}$ & $\left(1.8 \times{ }^{\circ} \mathrm{C}\right)+32$
\end{tabular}


(Table 1). Almost half of the nurseries that experienced anthracnose problems were located in U.S. Department of Agriculture cold hardiness zone $5,20 \%$ were located in zone 6 , and $\approx 17 \%$ were in zone 7 . None of the nurseries that responded from zone 4 had experienced anthracnose in wintercreeper euonymus. The percentages of nurseries reporting no anthracnose on wintercreeper euonymus were about equal among zones 4 through 8 , with $15 \%$ to $19 \%$ of production in each of the zones, except for zone 5 , in which about $25 \%$ of nurseries reported no anthracnose.

About $20 \%$ of the nurseries indicated that they grew wintercreeper euonymus in the past but have stopped production. Of nurseries that have stopped production, $45 \%$ said they stopped production during the past 5 years whereas $41 \%$ said they stopped production 6 to 10 years ago. Fifty-seven percent of nurseries indicated that production was stopped because of too many disease problems, whereas $14 \%$ said there was not enough market interest to warrant production. Fifty-two percent of the nurseries that had stopped production said they would not produce wintercreeper euonymus again, even if suitable disease control measures were available.

Of the nurseries currently growing wintercreeper euonymus, 66\% said they have disease problems. Of the nurseries with disease problems, $73 \%$ attributed those disease problems to anthracnose. Most respondents $(82 \%)$ said that annual percentage crop loss was from $1 \%$ to $25 \%$ of their crop.

Nurseries were asked about their management practices for controlling anthracnose on wintercreeper euonymus. Most of the nurseries that have anthracnose problems attempted control with fungicide applications (Table 2). Several fungicides were being used, but mancozeb and chlorothalonil were used by about half of the nurseries with anthracnose (Table 3 ). Some nurseries also attempt to control anthracnose symptoms by growing in shade and by timing the irrigation to minimize disease problems (Table 2). Of the nurseries that did not report anthracnose problems, about one-third apply fungicides whereas a few grow wintercreeper

Table 1. Geographical distribution of U.S. nurseries that grow or have grown wintercreeper euonymus with or without anthracnose.

\begin{tabular}{lcc}
\hline & \multicolumn{2}{c}{ Proportion of nurseries (\%) } \\
\cline { 2 - 3 } U.S. region & With anthracnose & Without anthracnose \\
\hline Northeast & $26.7^{\mathrm{z}}$ & 9.4 \\
Northwest & 3.3 & 21.9 \\
Midwest & 46.7 & 40.7 \\
Southeast & 13.3 & 15.6 \\
Southwest & 10.0 & 13.3 \\
\hline
\end{tabular}

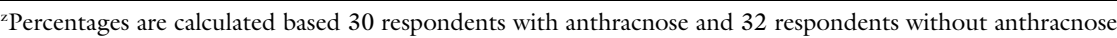

Table 2. Cultural practices used by U.S. nurseries to reduce anthracnose symptoms on wintercreeper euonymus.

\begin{tabular}{lcc}
\hline & \multicolumn{2}{c}{ Proportion of nurseries $(\%)^{\mathbf{z}}$} \\
\cline { 2 - 3 } Cultural practice & $\begin{array}{c}\text { With } \\
\text { anthracnose }\end{array}$ & $\begin{array}{c}\text { Without } \\
\text { anthracnose }\end{array}$ \\
\hline Fungicide application & 94.1 & 36.0 \\
Growing in shade & 32.4 & 12.0 \\
Irrigation timing (morning vs. afternoon) & 52.9 & 12.0 \\
Use of fans to circulate air & 0 & 4.0 \\
Other & 20.6 & 20.0 \\
\hline
\end{tabular}

${ }^{2}$ Percentages are calculated based 34 respondents with anthracnose and 25 respondents without anthracnose.

Table 3. Fungicides used to control anthracnose on wintercreeper euonymus in U.S. nurseries with or without anthracnose symptoms.

\begin{tabular}{lcc}
\hline & \multicolumn{2}{c}{ Proportion of nurseries (\%) $)^{\mathbf{z}}$} \\
\cline { 2 - 3 } Fungicide & 55.9 & Without anthracnose $^{\text {With anthracnose }}$ \\
\hline Mancozeb & 11.8 & 20.0 \\
Maneb & 26.5 & 4.0 \\
Copper hydroxide & 17.6 & 8.0 \\
Copper sulfate & 5.9 & 16.0 \\
Trifloxystrobin & 50.0 & 4.0 \\
Chlorothalonil & 41.1 & 4.0 \\
Thiophanate-methyl & 20.6 & 8.0 \\
Azoxystrobin & 5.9 & 0 \\
Myclobutanil & 17.6 & 0 \\
Propiconazole & 11.8 & 4.0 \\
Other & & 4.0 \\
\hline
\end{tabular}

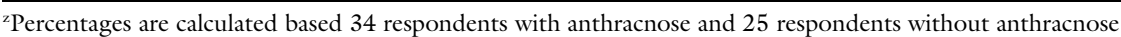

euonymus in shade and carefully time the irrigation. None of the nurseries with anthracnose and only one nursery without anthracnose use fans to circulate air around the crop.

Nurseries were asked about propagation practices. The parent source of wintercreeper euonymus planting stock was stock plants on site for $29 \%$ of nurseries surveyed with anthracnose and 28\% nurseries without anthracnose. Cuttings from plants on sale blocks were used by $56 \%$ of nurseries with anthracnose and $24 \%$ of nurseries without anthracnose. Rooted cuttings or liner stock were purchased from elsewhere by
$26 \%$ of nurseries with anthracnose and $4 \%$ of nurseries without anthracnose. During propagation, some nurseries use bleach $(35 \%$ of nurseries with anthracnose and 12\% of nurseries without anthracnose), Green-Shield (Whitmire Micro-Gen Research Laboratories, St. Louis; 18\% of nurseries with anthracnose and $12 \%$ of nurseries without anthracnose), or alcohol $(26 \%$ of nurseries with anthracnose and 16\% of nurseries without anthracnose) for sanitizing tools to reduce disease spread. About one-third of the nurseries did not sanitize tools used for propagation. 
Of the nurseries that reported having anthracnose, $88 \%$ reported that they shear the plants with hand shears or loppers, and $26 \%$ use a motorized shearing machine. Of the nurseries that reported no anthracnose problems, $48 \%$ used hand shears or loppers and $8 \%$ use a motorized shearing machine. Less than half $(42 \%$ of nurseries with anthracnose and $40 \%$ of nurseries without anthracnose) indicated that they sanitize shears as they work. Table 4 shows the frequency with which wintercreeper euonymus is sheared in nurseries that reported anthracnose problems.

Of the nurseries reporting anthracnose on wintercreeper euonymus, production was evenly distributed among 1-gal, 2-gal, and larger than 2 -gal pots (Table 5). One nursery reported growing wintercreeper euonymus in the ground. Just under half of the nurseries reported growing wintercreeper euonymus in full sun regardless of anthracnose severity. A few nurseries reported growing at least some cultivars in partial shade (data not presented). Shade intensities ranged from 25\% to $73 \%$. None of the nurseries used drip irrigation at any time. Most irrigate in the morning using overhead irrigation, but some irrigate in the afternoon with overhead irrigation.

Most nurseries overwinter wintercreeper euonymus in plastic houses, but some overwinter under fabric or with plants placed pot to pot (Table 6). No nursery used mulch for overwinter protection.

Nurseries were asked what cultivars of wintercreeper euonymus they produce. Many cultivars were listed, but 'Emerald Gaiety' and 'Emerald 'n Gold' were the two cultivars produced by the most nurseries regardless of anthracnose incidence (Table 7). Of the nurseries that cited anthracnose as a problem, more than half $(59 \%)$ listed 'Moonshadow' as a cultivar that they produce.

Symptoms of anthracnose incited by C. gloeosporioides on wintercreeper euonymus have been shown to increase as nighttime temperatures increase (Ningen et al., 2004), thus symptoms would be expected to be more prominent in plants grown in more southern areas, where temperatures tend to be warmer for a greater

Table 4. Frequency in which U.S. nurseries with anthracnose problems shear wintercreeper euonymus.

\begin{tabular}{lc}
\hline Frequency & $\begin{array}{c}\text { Proportion of nurseries } \\
\text { with anthracnose (\%) }\end{array}$ \\
\hline S3 weeks & $0^{\mathrm{z}}$ \\
Every 4 weeks & 3.0 \\
Every 5 weeks & 9.1 \\
Every 6 weeks & 27.3 \\
Every 7 weeks & 6.1 \\
Every 8 weeks & 21.2 \\
Other & 33.3 \\
\hline
\end{tabular}

${ }^{2}$ Percentages were based on 33 respondents.

Table 5. Cultural conditions under which wintercreeper euonymus plants are grown in U.S. nurseries that experience anthracnose and those that do not.

\begin{tabular}{lcc}
\hline & \multicolumn{2}{c}{ Proportion of nurseries $(\%)^{\mathrm{z}}$} \\
\cline { 2 - 3 } Cultural condition & $\begin{array}{c}\text { With } \\
\text { anthracnose }\end{array}$ & $\begin{array}{c}\text { Without } \\
\text { anthracnose }\end{array}$ \\
\hline Container grown, 1-gal pots & 52.9 & $-^{\mathrm{y}}$ \\
Container grown, 2-gal pots & 55.9 & - \\
Container grown, >2-gal pots & 52.9 & - \\
In ground & 2.9 & 48.0 \\
Full sun & 44.1 & 0 \\
Morning drip irrigation & 0 & 0 \\
Afternoon drip irrigation & 0 & 0 \\
Evening drip irrigation & 0 & 20.0 \\
Morning overhead irrigation & 55.9 & 8.0 \\
Afternoon overhead irrigation & 23.5 & 0 \\
Evening overhead irrigation & 2.9 & 0 \\
Other & 2.9 & 0
\end{tabular}

${ }^{2}$ Percentages are calculated based 34 respondents with anthracnose and 25 respondents without anthracnose ${ }^{\mathrm{y}} \mathrm{lgal}=3.7854 \mathrm{~L}$.

${ }^{x}$ Nurseries with no anthracnose did not respond to questions regarding container size or in-ground production.

Table 6. Methods of overwintering wintercreeper euonymus in U.S. nurseries with or without anthracnose.

\begin{tabular}{lcc}
\hline & \multicolumn{2}{c}{ Proportion of nurseries (\%) } \\
\cline { 2 - 3 } Overwintering method & With anthracnose & Without anthracnose $^{\mathbf{z}}$ \\
\hline Plastic houses & 88 & 44 \\
Under fabric & 9 & 4 \\
Mulched & 0 & 0 \\
Pot to pot & 18 & 12 \\
Other & 9 & 12 \\
\hline
\end{tabular}

${ }^{2}$ Percentages are calculated based 34 respondents with anthracnose and 25 respondents without anthracnose.

portion of the year than in more northern areas. However, survey results did not support this assumption, as a greater percentage of the nurseries that reported anthracnose problems were located in hardiness zones 5, 6, and 7, and a lower percentage of nurseries reported anthracnose in zones 8,9 , and 10 .

Several fungicides have been tested for effectiveness in controlling anthracnose on wintercreeper euonymus. Evidence of increased fungicide resistance has been noted since an- thracnose on wintercreeper euonymus was first described. LaMondia (200la, b) found that resistance to multiple fungicides was common and suggested that use of several different fungicides in a tank mixture or rotation provided better control of $C$. gloeosporioides than the use of a single fungicide when chemicals with different modes of action were used. Ningen (2003) tested chlorothalonil, trifloxystrobin, mancozeb, propiconazole, and thiophanate-methyl alone, in rotations, and in mixtures, 
Table 7. Wintercreeper euonymus cultivars currently produced or produced in the past by U.S. nurseries that do or do not experience anthracnose problems.

\begin{tabular}{|c|c|c|}
\hline \multirow[b]{2}{*}{ Cultivars produced } & \multicolumn{2}{|c|}{ Proportion of nurseries $(\%)^{\mathrm{z}}$} \\
\hline & With anthracnose & Without anthracnose \\
\hline Canadale Gold & 23.5 & 4.0 \\
\hline Canadian Gold & 5.9 & 0 \\
\hline Canadian Variegated & 2.9 & 0 \\
\hline Carrierei & 2.9 & 0 \\
\hline Carrierei var. coloratus & 5.9 & 8.0 \\
\hline Duet & 2.9 & 0 \\
\hline Emerald Beauty & 2.9 & 0 \\
\hline Emerald Cushion & 2.9 & 0 \\
\hline Emerald Gaiety & 73.5 & 44.0 \\
\hline Emerald 'n Gold & 79.4 & 36.0 \\
\hline Emerald Surprise & 8.8 & 8.0 \\
\hline Gold Prince & 5.9 & 0 \\
\hline Gold Splash & 17.6 & 4.0 \\
\hline Gold Spot & 8.8 & 0 \\
\hline Gold Tip & 2.9 & 0 \\
\hline Green Lane & 17.7 & 0 \\
\hline Harlequin & 20.6 & 12.0 \\
\hline Ivory Jade & 17.6 & 1.7 \\
\hline Kewensis & 11.8 & 8.0 \\
\hline Microphylla Variegata & 8.8 & 8.0 \\
\hline Minimus & 2.9 & 0 \\
\hline Moonshadow & 58.8 & 12.0 \\
\hline Sarcoxie & 20.6 & 8.0 \\
\hline Silver Queen & 5.9 & 0 \\
\hline Sun Spot & 11.8 & 12.0 \\
\hline Sunrise & 8.8 & 8.0 \\
\hline Thunderbolt & 0 & 4.0 \\
\hline Variegatus & 5.9 & 0 \\
\hline Vegetus & 20.6 & 8.0 \\
\hline
\end{tabular}

${ }^{2}$ Percentages are calculated based 34 respondents with anthracnose and 25 respondents without anthracnose.

and found that mancozeb alone or in rotations with chlorothalonil provided better control of C. gloeosporioides than mixtures or rotations of fungicides without mancozeb or chlorothalonil. However, no fungicide eliminated $C$. gloeosporioides symptoms. Although the fungicides found most effective (mancozeb or chlorothalonil) were used by many of the respondents, many fungicides that have been shown to be ineffective are also being used (Table 3 ). Respondents were not asked whether they rotate fungicides or apply tank mixtures of fungicides.

Research has shown that growing wintercreeper euonymus in partial shade $(63 \%, 73 \%$, or $80 \%)$ can almost eliminate anthracnose symptoms compared with growing in full sun (Ningen et al., 2005). Likewise, plants irrigated in the afternoon had fewer anthracnose symptoms than plants irrigated in the morning with overhead irrigation (Ningen et al.,
2005). Only a few survey respondents indicated that they grow wintercreeper euonymus in shade, and more respondents irrigate in the morning than in the afternoon.

The results of this survey show that all the cultural practices addressed were used by producers regardless of presence or absence of anthracnose symptoms. Thus, no recommendations for incorporating or eliminating practices from management of wintercreeper euonymus can be made from the survey. Instead, the study suggests that outreach efforts to inform producers of best management practices for this crop have not been effective. Based on past research, production of less susceptible cultivars under shade with afternoon irrigation is recommended.

\section{Literature cited}

Boyer, C.R., J.C. Cole, and K.E. Conway. 2007. Effectiveness of copper sulfate pen- tahydrate, mancozeb, and hydrogen dioxide in controlling anthracnose on wintercreeper euonymus. J. Environ. Hort. 25:21-26.

Cole, J.T., J.C. Cole, and K.E. Conway. 2005. Effectiveness of selected fungicides applied with or without surfactant in controlling anthracnose on three cultivars of Euonymus fortunei. J. Appl. Hort. 7:16-19.

Dirr, M.A. 1998. Manual of woody landscape plants. Their identification, ornamental characteristics, culture, propagation and uses. 5th ed. Stipes Publishing, Champaign, IL.

LaMondia, J.A. 2001a. Management of Euonymus anthracnose and fungicide resistance in Colletotrichum gloeosporioides by alternating or mixing fungicides. J. Environ. Hort. 19:51-55.

LaMondia, J.A. 200lb. Resistance of the Euonymus anthracnose pathogen, Colletotrichum gloeosporioides, to selected fungicides. J. Environ. Hort. 19:47-50.

Mahoney, M.J. and T.A. Tattar. 1980a. Causal organism for spot anthracnose disease identified. Amer. Nurseryman 151:77-78.

Mahoney, M.J. and T.A. Tattar. 1980b. Identification, etiology, and control of Euonymus fortunei anthracnose caused by Colletotrichum gloeosporioides. Plant Dis. 64:854-856.

Ningen, S.S. 2003. Chemical and cultural controls of anthracnose on Euonymus fortunei. Department of Horticulture and Landscape Architecture, Oklahoma State University, Stillwater, OK, MS thesis.

Ningen, S.S., J.C. Cole, and K.E. Conway. 2004. Cultivar and night temperature affect severity of anthracnose on Euonymus fortunei. HortScience 39: 230-231.

Ningen, S.S., J.C. Cole, M.W. Smith, D.E. Dunn, and K.E. Conway. 2005. Increased shade intensity and afternoon irrigation decrease anthracnose severity on three Euonymus fortunei cultivars. HortScience 40:111-113.

Schupbach-Ningen, S.L., J.C. Cole, J.T. Cole, and K.E. Conway. 2006. Chlorothalonil, trifloxystrobin, and mancozeb decrease anthracnose symptoms on three cultivars of wintercreeper euonymus. HortTechnology 16:211-215.

Whitcomb, C.E. 1996. Know it \& grow it III. A guide to the identification and use of landscape plants. Lacebark Publications, Stillwater, OK. 